

\title{
The money-happiness relationship in transition countries: evidence from Albania
}

\author{
Leonardo Becchetti, University of Rome Tor Vergata \\ Sara Savastano University of Rome Tor Vergata
}

\begin{abstract}
With an empirical analysis on a panel of individuals living in a transition country (Albania) we document that the impact of money on happiness does not depend only on the pecuniary outcome but also from aspirations and conditions leading to its determination. Additional factors which matter are the self perceived economic status and the share earned from remittances (and, more weakly, from social assistance). By looking at different sides of the phenomenon we find that these factors affect levels, changes in income and the probability of "being frustrated achievers". Finally, differently from what happens in developed countries, higher income levels are negatively and not positively correlated with the probability of frustrated achievement supporting the hypothesis that individuals in transition countries are not in the upper side of a concave happiness-income relationship.
\end{abstract}

Key words: life satisfaction, remittances, economic status.

\section{Introduction}

One of the most interesting applications of the empirical life satisfaction literature is the test of standard theoretical assumptions on the relationship between income and the utility function. ${ }^{1}$

As it is well known, theoretical models usually look at this connection by assuming a stable concave nexus between income and utility which postulates nonsatiation. The well known rationale is that money is a mean of exchange which can purchase an ample variety of goods and services. Even in the extreme case of contemporaneous satiation for all material goods money may still be regarded as very useful to conquer immaterial goods such as status, power and fame. As a consequence, its marginal utility should keep on being non negative, even when individuals dispose of high income levels.

\footnotetext{
${ }^{1}$ Utility and happiness are not exactly the same concept. But, by definition, something is useful if it enhances our wellbeing and life satisfaction. Therefore, a straightforward link between utility and happiness may be easily established and such link is conventionally assumed in most of the happiness literature. However, the reflection over this correspondence is still ongoing and open issues are those whether self declared life satisfaction: i) relates to life time or to instantaneous utility; ii) is forward looking incorporating expectations of future happiness changes (a sort of permanent happiness hypothesis). By working on questions which ask people to judge their life satisfaction over a long period we depart from utility/happiness conceptions too related to instantaneous utility, pleasure or momentary affect (Kahneman et al., 2004) and get closer to a lifetime utility concept.
} 
This short premise explains why we decide to look in this paper not just at determinants of levels and changes in income but also at strong (weak) frustrated achievement. We define the latter as the circumstance under which positive changes in income lead to negative (or non positive) changes in life satisfaction (Graham and Pettinato, 2002). The rationale is that this is a particular, simple and easily understandable way of looking at the dynamics of the income-life satisfaction relationship and testing the validity of the non satiation hypothesis. In our frustrated achievement estimates the magnitude of significant regressors may be read as the impact of such regressors on the probability of overcoming the satiation point in the life satisfaction-income relationship. An observationally equivalent (and more sophisticated) rationale for the existence of frustrated achievement put forth in the literature is that the instantaneous income/utility function (which is assumed as having no satiation points) may change shape across time when some income related concurring factors (relative income, dynamics between monetary expectations and achievements) are at work (Frey and Stutzer, 2002; Clark et al., 2006).

Three findings of our research provide new original evidence in this debate. A first important result documents that, differently from what measured in developed countries (Becchetti and Rossetti, 2007), higher income is negatively and not positively correlated with frustrated achievement. This finding leads us to infer that individuals in transition countries are not in the upper side of a concave happiness-income relationship. Other two main results of our paper provide evidence in favour of this hypothesis and illustrate that there is something more complex beyond the simplified textbook concave life satisfaction/income relationship.

More specifically, we observe that two income related factors significantly affect such relationship after controlling for income levels. These factors are the self perceived affluence status and the way income is earned (more specifically, the share of remittances and social assistance on total income). This last result may be interpreted also as a proof of the limits of the consequentialist approach to economics (what matters is not just the monetary outcome but also the circumstances under which 
the outcome is obtained). The validity of this interpretation is tested in the paper vis-à-vis alternatives identifying variables affecting future expected income in such factors.

Our findings are proven to be robust when the phenomenon is investigated from two different and more traditional perspectives, that is, when the dependent variable is not the dichotomous measure of frustrated achievement but the level or the rate of change in life satisfaction.

The choice of a transition country for our investigation is not casual. The advantage of working on a non high income country is that we can observe more variability in ways of earning income, with a higher impact of social assistance and measures against poverty and a specific role of remittances. In addition to it, we can see whether frustrated achievement is an issue only for individuals who already achieved high living standards or also for those starting from much lower levels.

The paper deals with all these issues and is divided into six sections (including introduction and conclusions). In the second section we provide a short discussion of the income-happiness literature relevant to the focus of our research. In the third and fourth sections we show and discuss descriptive and econometric findings respectively, while in the fifth section we evaluate the plausible interpretations for the role of the remittance share in our estimates. The sixth section concludes.

\section{A brief sketch of the income-happiness literature}

The happiness-income literature may be conventionally considered as starting from the well known Easterlin paradox which documents the concurring presence of a rising real per capita GDP and a stationary (or slightly declining) share of self declared very happy people in postwar US (for a similar conclusion see also Schor, 1991; Frank, 1985 and Scitowsky, 1976). ${ }^{2}$ This descriptive

\footnotetext{
${ }^{2}$ Evidence supporting the paradox is also reported by Blanchflower and Oswald (2004) for the UK, Frey and Stutzer (2002b) on a large sample of countries using data from the World Database of Happiness and the U.S. Bureau of Census and Veenhoven (1993) for Japan over the period 1958-1987. In spite of it, the Easterlin paradox is not in itself a regularity always confirmed across countries and time. When Castriota (2006) repeats the Easterlin exercise on Eurobarometer data for some European countries in the last decade he actually finds that the paradox applies to
} 
paradox stimulated many researchers to go deeper into the analysis and estimate econometrically the income-happiness relationship.

Almost all the econometric studies which follow have found a positive and significant correlation between income and happiness which seem to contradict the paradox both in cross-sectional and panel data. The most clever approaches among them aim to overcome the endogeneity (two-way causality) problem in the income-happiness relationship showing that, almost fully exogenous income shocks (lottery wins, changes in real income in Russia and East Germany after transition and reunification, tsunami related income losses) produce positive and significant changes in life satisfaction (Gardner and Oswald, 2006b; Frijters et al., 2004a, 2004 and 2006, Becchetti and Castriota, 2009).

The Easterlin paradox has also been directly criticized by Stevenson and Wolfers (2008) and by Hagerty and Veenhoven (2003) to which Easterlin (2009) replies. The querelle may be also viewed through as a difference in estimating approaches. Estimates of short run effects of income are all against the Easterlin hypothesis while evidence on long term effects is closer to the paradox.

Rationales for the coexistence of these two apparently contradicting facts (the Easterlin paradox and the robust income-happiness nexus) have been provided by several competing theories (relative income, hedonic adaptation, positional competition, comfort/stimulation trade-off, crowding out of relational life).

The relative income contributions document that people do not look just at their own income but also compare it with the average income of their reference group (Dorn, Fischer, Kirchgassner and Sousa-Poza, 2007; Ferrer-i-Carbonell, 2005). This positional competition may create "treadmill effects" by which, under the extreme case when only relative and not absolute income matters, an equal increase in income of all the reference group does not raise individual life satisfaction. Put in other terms, since status may be considered as a zero sum game, the dominance of the relative

Germany but not to Italy where a quite strong positive relationship between the happiness and per capita income is found. 
income effect ${ }^{3}$ and of "positional competition" may paradoxically eliminate any significant impact of a positive change in personal income (Dusenberry, 1949; Frank, 2005 and Layard, 2005). Beyond this extreme example consider however that absolute and relative effects generally coexist and the positive effect of an absolute increase in income extends to the higher tax inflows which can increase quantity and quality of public goods and services.

According to a different interpretation of the puzzle (the hedonic adaptation hypothesis), it is the comparison with oneself in the past, and not with peers in the present, which matters. In this framework the catching up of expectations on realizations shifts down the instantaneous utility of income anytime a higher income threshold is reached (this implies that past income levels tend to affect negatively current income). As a consequence, the observed intertemporal association between happiness and income becomes much flatter than that postulated by instantaneous standard utility functions (Frey-Stutzer, 2002). This interpretation is not at odd with the empirical evidence showing that, for a given level of income, higher aspirations and expectations have a negative effect on SWB (Macdonald and Douthitt, 1992; Stutzer, 2004).

From another perspective Scitowsky (1976) argues that affluence does not always generate higher life satisfaction due to a trade-off between comfort and stimulation. Higher comfort dampens stimulation for costly investment in those goods which may make individuals happier in the long run.

All these theories shed some light on the complexity of the income-happiness relationship even though a lot still needs to be done. The way in which we intend to add value to this literature is by getting advantage of the wide variability of ways of earning income in a transition country where both social assistance and remittances play a relevant role. The focus on a transition country in itself will be useful to verify how self perceived economic status may affect frustrated achievement

\footnotetext{
${ }^{3}$ Arguments on the relevance of the relative income hypothesis are proposed by Dusenberry (1949) and, more recently, by Frank (2005), Layard (2005) and Ferrer-i-Carbonell (2005).
} 
and to which extent the latter may be relevant in a long process of (desired) convergence to a still very distant goal (the economic wellbeing of neighbouring European countries).

From this point of view the specific literature of the determinants of happiness in transition generally presents results which are very similar to those in high income countries with respect to the effect of age, education, unemployment and marriage (Ravaillon and Loskin, 2002; Hayo, 2004; Hayo and Sefiert, 2003), even though there is some consensus that average aggregate levels of happiness are somewhat inferior (Helliwell, 2003, Sanfey and Teksoz, 2007). ${ }^{4}$ Another interesting difference in transition countries is related to the effect of income comparisons. Senik (2004) finds support for the Hirschman's (1973) tunnel effect hypothesis, showing that growth (or simply higher levels) in the relative income of the peer group affect positively and not negatively individual wellbeing. Another specificity of transition countries is that self-employed are usually happier than waged workers (Senik, 2004). Overall, these differences seem to illustrate a dynamic and competitive environment in which opportunities of catching up rapidly with the standard of living of high income countries are highly valued.

\section{Descriptive findings}

Following Becchetti and Rossetti (2007) we define as "strongly frustrated achiever" an individual for whom we record, in a given year with respect to the previous one, a negative change in self declared life satisfaction, accompanied by a positive variation in real equivalised ${ }^{5}$ household income.

\footnotetext{
${ }^{4}$ As it is well known interpersonal (and even more intercountry) comparisons based on cardinal indicators are subject to cultural biases, with the latter suffering from language differences in the same definition of happiness (terms such as happiness, gluck (German), bonheur (French) e felicità (Italian) have different nuances). The most recent approach to tackle this problem is that of showing vignettes illustrating a given situation to respondents of different countries and asking them to judge the level of happiness of individual(s) in the picture on the usual cardinal scale (King and Wand, 2007).

${ }^{5}$ Equivalised income is commonly used in most economic well-being comparison (within and across countries) studies to adjust income in order to take into account the differences in material needs for families of different sizes. The two main approaches followed are the revealed preferences and the stated level of utility (Schwarze, 2003) approach.
} 
As a consequence, frustrated achievement is measured by the following dummy variable

$$
S F A\left\{\begin{array}{l}
=1 \mid \Delta_{t-(t-1)} L S A T<0 \quad \text { and } \quad \Delta_{t-(t-1)} R Y>0 \\
=0 \quad \text { otherwise }
\end{array}\right.
$$

where LSAT is the declared level of life satisfaction, RY is real equivalised household income for the same individual and $\Delta_{\mathrm{t}-(\mathrm{t}-1)}$ indicates a variable change from period t-1 to period $\mathrm{t}^{6}$

We define in parallel the condition of weak frustrated achievement as

$W F A\left\{\begin{array}{l}=1 \mid \Delta_{t-(t-1)} L S A T \leq 0 \quad \text { and } \quad \Delta_{t-(t-1)} R Y>0 \\ =0 \quad \text { otherwise }\end{array}\right.$.

To analyse the money-happiness relationship in transition countries, we make use of the Living Standard Measurement Survey (LSMS) based on household interviews in 2002 and 2003, run by the Institute of Statistics of Albania (INSTAT) with support from the World Bank. The survey provides information on household characteristics, dwelling and utilities, education, health, employment, transfers and social assistance, other income sources, migration, fertility, subjective poverty, agriculture, and non-farm enterprises. The sample selected from the LSMS for the panel was designed to provide a nationally representative sample of households and individuals in Albania. The questions related to subjective well-being were asked to one respondent only in the household, therefore, the analysis will be at individual level, by merging the respondent from the two years. Excluding uncoded and non interviewed households, we end up with a sample of 1,780 individuals surveyed in both years. Given the attrition between the two year surveys our analysis

In the first approach differences in scale economies are determined either by actual consumption patterns or by the socalled "expert scales" which are based on expert judgments or political considerations. In our definition of FA we use the OECD scale, developed by Haagenars et al. (1994), which assign a value of 1 to the household head, of 0.5 to each additional adult member and of 0.3 to each child. Robustness checks with non equivalised household income and household income equivalised using different scales do not change substantially our findings.

${ }^{6}$ The exact formulation of the question in the GSOEP is as follows "In conclusion, we would like to ask you about your satisfaction with your life in general. How satisfied are you with your life, all things considered?" Please answer according to the following scale: "0" means completely dissatisfied, "10" means completely satisfied.

${ }^{7}$ In 2002, there were 1,782 interviewed individuals (917 urban/863 rural/2 uncoded). The second wave, 2003, initially reports information on 2,155 individuals (1,780 interviewed/375 not interviewed). The majority of the non-interviewed individuals were due to split-off moves out of the country $(\mathrm{N}=348)$. Other 23 individuals had moved out of scope within Albania (in places where they refused or were not in condition to answer). Only 4 households had moved and could not be traced. 83 households had moved and were traced to their new addresses. 
focused on a restricted sample of 1,558 individuals for which we have detailed information in both rounds.

We use this sample to analyse the determinants of frustrated achievement and the determinants of levels and changes of life satisfaction. Our descriptive findings show that the share of strongly frustrated achievers is of 11.17 percent (Table 1) accounting for 18.87 percent of total achievers. If we compare these figures with results from Germany from a GSOEP (German Socioeconomic Panel) sample of 168,626 observations collected from 1984 to 2004 where SFA amounted to 16 percent and around one third of achievers were strongly frustrated (Becchetti and Rossetti, 2007), we may conclude that frustrated achievement is a less relevant phenomenon in Albania.

If we relax our definition and look at weakly frustrated achievers we find a much larger share (42.81 percent). To understand what causes frustrated achievement we first look at descriptive features of strongly (or weakly) frustrated achievers versus non frustrated achievers and, more specifically, at the significance of the differences in mean between the two samples. Variables considered in descriptive and econometric findings are presented inTable 2. Differences in means in Tables 3a-3b.

An important preliminary check relates to the distribution of income changes for frustrated and non frustrated achievers. Figure 1 clearly shows that weak frustrated achievement cannot be justified by systematically lower or insignificant changes in real equivalised household income.

When we analyse the difference between frustrated and non frustrated achievers we find that income matters and that many income related effects are also important.

Frustrated achievement (defined in the weak sense) is significantly affected by the level of income (which is 40 percent higher for non frustrated achievers). This finding is in striking contrast with the concavity assumption which implies that returns from income growth in terms of life satisfaction are diminishing as far as the level of income gets higher (or is compatible with the hypothesis of non convex traits for low levels of income in which our respondents should be placed). With regard to the composition of income frustrated achievers have a significantly lower share from remittances 
(5 against 8 percent for strongly frustrated and 5 against 9 percent for weakly frustrated achievers), a smaller share from wage (around 41 against 50 percent) and a significantly higher share from social assistance (around 45 versus 38 for strongly frustrated and 47 against 32 percent for weakly frustrated achievers).

To interpret the social assistance variable we must consider that the Albanian Social Safety Net consists of four cash social assistance programs: i) a targeted poverty benefit in cash (called Ndihme Ekonomike or economic aid, which provides a means-tested cash benefit for eligible families with little or no earned income); ii) a regular monthly allowance to those disabled since childhood; iii) a price compensation paid to pensioners and their families, and iv) a program of social care services for orphaned, disabled, and elderly people. In 2002, averaged across all households, public transfers represented 21.3 percent of household income. Private transfers represented a further 14.4 percent. Together, therefore, these reported transfers provided more that one Lek out of every three. This makes them on aggregate a more important source of household income, on average, than either earnings from employment (31.5 percent) or agriculture (25.0 percent).

Relative income also seems to matter. A significantly larger share of frustrated achievers (around 70 percent against 59 among non frustrated achievers) is below the average sample district income. If we move from the weak to the strong definition we find that the role of self perceived economic status becomes strong and significant: on a scale from 1 (the poorest) to 10 (the richest), frustrated achievers (under the strong definition) feel themselves significantly richer than non frustrated ones (4.4 against 3.4). This implies that the impact of income changes on life satisfaction is not independent from the self perceived affluence status and that a higher self perceived affluence status reduces the marginal effect of income changes on life satisfaction. Note that only with the multivariate analysis which follows we can verify whether the two effects (level of income and self perceived wealth status) measure two independent factors or are just proxies of the same 
phenomenon (i.e. the relationship between life satisfaction and income levels under the hypothesis that expectations closely follow achievements)

Among non income effects the strongest seems that of age (significant under both the weak and strong definition) with frustrated achievers being significantly older and with a larger proportion of individuals in the 60-80 age cohort. Individuals with a previous migration experience ${ }^{8}$ are less likely to be (weakly) frustrated achievers, while possession of a tv color and of a sewage system is significantly and positively related to (strong) frustrated achievement.

The income and non income effects described above are evaluated independently in these descriptive statistics. Since they are likely to be correlated, we need to check whether they remain significant in an econometric estimate in which their effect is calculated net of all other concurring factors.

\section{Econometric findings}

Econometric findings confirm that most of the previously mentioned variables are indeed significant also in a multivariate analysis. Estimates are run on the sample of achievers (individuals with nonnegative changes in income) using household income equivalised with the OECD scale.

In Table 4, column 1 we look at factors affecting significantly the dichotomous dependent variable of weak frustrated achievement. ${ }^{9}$ Four income variables are strongly significant: on the one side, the share of real household income from social assistance and the self declared economic status

\footnotetext{
${ }^{8}$ World Bank report on Albania underlines that "Migration is perhaps the single most important political, social, and economic phenomena in post-communist Albania". The report calculates that around one-fifth of the total population left the country since 1990 and that large-scale internal migration movements occurred from rural to urban areas. Remittances are calculated to be the main source of foreign exchange (larger than the sum of export and foreign direct investment) and amounted to 14 percent of GDP in 2003 (World Bank, 2003).

${ }^{9}$ We focus on weak and not on strong frustrated achievement given that the latter presents a small share of positive cases for our logit estimate. We could equally define weak frustrated achievement as non happiness increasing achievement but we maintain the traditional denomination for simplicity.
} 
significantly increase the likelihood of frustrated achievement, while, on the other side, the share of income from remittances and the level of household income are significant but in the opposite direction.

From a quantitative point of view doubling the share of income from social assistance increases by 18 percent the probability of being a frustrated achiever, while doubling the share from remittances reduces it by 23 percent. The (negative) elasticity of income levels is much lower and around 2 percent. $^{10}$

Other controls which are significant in the estimate are age and unemployment status (with positive effects) and catholic religion and absence of migration episodes in the recent past (from 1997) (with negative effects). Our results do not change much when we use the log of the income level (Table 4, column 2) except for the significance of the same income variable. Age is negatively related to happiness. Although we do not report results, there is no evidence of a U-shaped relationship between age and happiness. ${ }^{11}$ The difference in the income results is probably due to the fact that the log variable flattens the upper values of the income distribution. This may eliminate the significance of the effect on weak frustrated achievement reducing the extent of income variations at high income levels.

In terms of magnitude, catholic religion reduces by 20 percent the probability of frustrated achievement. The result is consistent with evidence on religion as shock absorber (Clark and Lelkes, 2005). If frustrated achievement is related to concurring unobservable shocks, religion has the power of reducing their effects on happiness. Another explanation is that religion trains believers to gratitude (to thank for what received and be satisfied with one's standard of living) and therefore reduces adaptation effects of income achievements.

\footnotetext{
${ }^{10}$ Even though we cannot completely rule out the possibility of reverse causation, we argue that the hypothesis is more unlikely for the remittance share variable. In this case in fact, if we do not believe to an almost deterministic genetic transmission, it is hard to imagine that the happiness reaction to income changes of the interviewed individuals could affect the earning capacity of a migrant relative.

${ }^{11}$ For a recent discussion on the age-happiness puzzle see Frijters and Beatton (2008).
} 
Unemployment has exactly the same impact of catholic religion but with the opposite sign. This implies that unemployment status raises by 20-22 percent the probability of frustrated achievement. The latter is an interesting result since it shows that, even the absence of negative income shocks (frustrated achievers, by definition, register a non lower income with respect to the previous year, even though they may suffer from persistence of low income levels) cannot compensate the disutility arising from the unemployment status.

Another relevant finding is related to the impact of respondent migration. Absence of a past migratory record reduces by 30 percent the significance of frustrated achievement. The relative income effect may again be a plausible explanation here. Ceteris paribus, individuals who have faced the wellbeing of richer countries (migration is almost always versus richer countries) may be more likely to become frustrated achievers because they do not compare only their current economic status with their income in the past but also with the average wellbeing in the past hosting country. It is not possible however to disentangle this interpretation with one based on omitted factors (i.e. a time invariant personality trait of higher propensity to satisfaction which affects both the probability of frustrated achievement and the decision to migrate).

As it is well known it is very difficult to avoid endogeneity when measuring the effect of health on life satisfaction. It is not advisable therefore to use satisfaction about health as a regressor in happiness regressions and even the number of visits to the doctor may be suspicious since more unhappy types may be more likely to be hypochondriac. Still, health conditions are a very important factor to control for. A proper variable to use may be that related to costs related to medical visits (hypochondriac individuals may exaggerate with doctor visits but costs should limit their excess). We use such variable and find that it is strongly significant and with large impact. Doubling such costs implies an increase in the probability of frustrated achievement by more than 90 percent. 


\section{Interpretation of our findings}

A first important finding in our results is that the hypothesis of concavity in the income-happiness relationship is strongly rejected. Differently from what expected, frustrated achievement is more likely to happen at lower than at higher income levels. This is exactly the contrary of what happens in empirical studies on highly developed countries (i.e. Germany in Becchetti and Rossetti, 2007). Our finding is however reasonable if we look at the cross-sectional distribution of the per capita income/average life satisfaction relationship among different countries (Di Tella, MacCulloch and Oswald, 2003; Helliwell, 2003; Rehdanz \& Maddison, 2005). Even though intercountry happiness comparisons suffer from strong methodological problems (starting from the cultural differences in the definition and perception of the happiness concept), the distribution of country observations in the space of the two variables closely resembles that of the concave income/happiness relationship. We are therefore led to believe that per capita income of a transition country like Albania is still in the region in which increases in income have non diminishing effects on happiness.

The status result is somewhat expected. For a given level of income, a higher self perceived economic status increases the difference between expectations and achievements and is therefore likely to affect negatively life satisfaction. Our finding is consistent with the outcome of a clever penny matching experiment in which McBride (2007) shows that, by changing the randomly generated odds of head/tail outcomes in a way that does not affects players' strategies, the observed outcome generates lower satisfaction the higher the expected outcome. ${ }^{12}$

Another interesting finding is the negative and significant effect of remittances. A first interpretation of it is based on an insurance rationale. As it is well known remittances are much

\footnotetext{
${ }^{12}$ To make an example, with a 80/20 distribution of random head/tail probabilities, the player strategy is "head" and the expected value of playing one penny is $4 / 5$. By changing the distribution to 60/40 the player strategy remains "head" but the expected value falls to $3 / 5$. An equal outcome produces higher happiness in the second than in the first case. If we assume that self perceived economic status is strictly related to income expectations, this result parallels our empirical one.
} 
more stable (Ratha, 2003) than foreign aid and foreign investment, when for stability we intend reduced sensitivity to economic shocks and the business cycle of the recipient country. A reduced correlation between economic dynamics in the origin and host countries and the solidarity motivation of remittances are such that remittances may even become anticyclical. This interpretation implies that, for a given level of income, household income with a larger share of remittances is a less risky financial asset and, as such, it should increase life satisfaction of risk averse individuals.

The second interpretation (relational motive) is based on motivational complexity and suggests that remittance receivers may be, coeteris paribus, happier when their income has a larger remittance share if they have altruistic or relational preferences (that is, if their utility depends also on the utility of their relative or from the quality of the relationship with the latter). This is because a remittance is a signal of two things: the success of the migrated family component in a different country and the strength of the relational tie with the non migrated family even when living at distance.

The two interpretations are not uncorrelated since one of the determinants of remittance stability or anti cyclicality is exactly the solidarity motive which induces migrants to maintain or reinforce their monetary support under harsher economic conditions in the home country.

If we take together the remittance and the social assistance findings we discover that our results may be seen as the hidden side of the well known Andreoni's impure altruism result. Andreoni (1989 and 1990) documents that, on the side of the sender, for an equivalent impact on the receiver, a direct donation is preferred to higher taxes which will be used for the same purpose and have the same effectiveness. If we follow this interpretation our findings show that the same occurs on the side of the receivers who prefer, for an equivalent impact on household income, a remittance (direct donation from a relative) to social assistance. Hence, if the relational rationale holds we may see our 
result as another example which contradicts consequentialist principle according to which what matters is just the outcome of actions and not the circumstances which led to them. ${ }^{13}$

To discriminate between these two interpretations we may reasonably assume that the relational/altruistic explanation is independent (or less dependent) from the size of the share (the decision of doing it, independently from the economic effect, matters), while this is not the case for the insurance explanation which becomes irrelevant if the remittance share is negligible.

We therefore split the remittance share variable in two regressors. The first is a dummy which takes value of one when individuals have a remittance share lower than 25 percent of their income and the second when the remittance share higher than that threshold. Both variables remains significant and almost with the same magnitude. We perform sensitivity analysis on the threshold and find that our result persists up to a lower bound of remittances accounting for 15 percent of total income, with coefficients being very close in magnitude (Table 4, column 4). Such findings are more in favour of the insurance hypothesis. Even though the magnitude of the coefficient is quite insensitive to the share of remittances on total income at high percent levels, it however becomes no more significant below the 15 percent threshold.

\section{From frustrated achievement to level and rates of changes in life satisfaction}

Estimates on the determinants of frustrated achievement show that some driving factors explain why more money may not lead to higher income satisfaction. Such factors are themselves directly related (economic status, way in which income is achieved, level of income) or not directly related (unemployment, health, religion) to income or income status.

\footnotetext{
${ }^{13}$ Another formulation of the anti-consequentialist principle is the well known definition of procedural utility (Frey, Benze and Stutzer, 2003) defined by the authors as "the well-being people gain from living and acting under institutionalized processes as they contribute to a positive sense of self, addressing innate needs of autonomy, relatedness and competence." In such case non exclusive care for one's own payoff does not depend on other regarding preferences but on the modalities which led to the final outcome. In our case it depends both on other regarding preferences and on the specific modalities leading to the outcome.
} 
In this robustness check we want to verify which is the impact of these variables on levels and rate of change of happiness. In Tables 5 and 6 we report estimates for the two different specifications. What we observe is that unemployment, health, share of remittances, income level and economic status confirm their significance in a direction consistent with that in previous estimates. The only variable which looses significance is the share of income earned from social assistance.

More specifically, in the level estimate presented in Table 5, we find that income is now unequivocally positive also when measured in logs. A second relevant difference is that higher education significantly and positively correlates with levels of happiness even though it doesn't with frustrated achievement.

Another interesting finding is the relationship between happiness and migration. Individuals who never migrated display higher (even though weakly significant) happiness levels and individuals who migrated to Italy register significantly less positive changes in happiness in the two year period considered (Table 6). Such findings are not at odds with the hypothesis that comparisons with Western neighbouring countries may matter and may be stronger for those more exposed to them due to migration.

The relationship between levels of happiness and the remittance share documents that the impact is different when the share is above or below the 25 percent threshold. In both level and first difference estimates, only the above threshold share is significant. This result (combined with that on the determinants of frustrated achievement) may tell us that the insurance rationale is dominant with respect to the purely relational one given that the share matters only when it accounts for a relevant part of income. 


\section{Conclusions}

The analysis on the determinants of frustrated achievement and life satisfaction on a sample of individuals living in a transition country such as Albania provides interesting insights on the differences between factors associated with happiness vis à vis high income countries.

Even though we are fully aware that with such a short time spell it is very difficult to disentangle causality directions in our results (and we do not try to do it), we however regard our inquiry as highly interesting given the rarity of studies and data which shed light on happiness dynamics in transition countries.

Frustrated achievement seems a much less relevant phenomenon here and, more important, the likelihood of its occurrence is negatively affected by levels of income (a result which at the opposite of what found in high income countries). Frustrated achievement is also significantly related to self perceived economic status and conditions under which income has been earned. Given the negative (positive) impact of the share of income earned from remittances (social assistance), frustrated achievement seems more related to the perception of personal and household autonomous earning capacity. More specifically, the remittance effect disappears once we fall below a minimum threshold in the share of remittances over total income. This suggests that the economic significance is a necessary condition for this effect to hold. Such findings seem consistent with the picture of a dynamic society which strives to bridge the distance with high income countries, a society in which economic success and the capacity of living up with one's own economic expectations and domestic or foreign reference group incomes is highly valued. 


\section{References}

Andreoni, J. 1989, "Giving with Impure Altruism: Applications to Charity and Ricardian Equivalence”, Journal of Political Economy, Vol. 97 pp.1447-58.

Andreoni, J. 1990, "Impure Altruism and Donations to Public Goods: a Theory of Warm-Glow Giving”, Economic Journal, Vol. 100 pp.464-77.

Becchetti L. Rossetti F., 2007, When money does not buy happiness: the case of "frustrated achievers" CEIS working paper 251 and Journal of Socioeconomics forthcoming

Becchetti L. Castriota S., 2009, The effects of a calamity on income and wellbeing of poor microfinance borrowers: the case of the 2004 Tsunami shock" Journal of Development Studies, forthcoming

Blanchflower, D. \& Oswald, A. J., 2004, "Well-being Over Time in Britain and the USA," Journal of Public Economics, Elsevier, vol. 887-8,, pages 1359-1386, July

Castriota, S., 2006, Education and Happiness: a Further Explanation to the Easterlin Paradox? mimeo

Clark A., and O Lelkes, 2005, "Deliver Us from Evil: Religion as Insurance," PSE Working Papers 2005-43, PSE Ecole normale supérieure,.

Clark, A.E., Frijters, P., Shields, M.A., 2006, "Income and Happiness: Evidence, Explanations and Economic Implications”, Paris Jourdan Sciences Economiques, working paper 2006-24.

Di Tella, R., MacCulloch, R. and Haisken-DeNew, J.P. 2005,. "Happiness adaptation to income and to status in an individual panel". Harvard Business School Working Paper.

Dorn, D., Fischer, J. A., Kirchgassner, G., \& Sousa-Poza, A. 2007, "Is It Culture of Democracy? The Impact of Democracy, and Culture on Happiness" Social Indicators Research, 823, 505-526.

Douthitt, R.A., MacDonald, M., and Mullis, R., 1992, "The Relationship Between Measures of Subjective and Economic Well-Being: A New Look." Social Indicators Research, 26 June,: 407-22.

Duesenberry, J.S., 1949, Income, Saving and the Theory of Consumer Behavior. Harvard Univ. Press, Cambridge,

Ferrer-i-Carbonell, A., 2005, "Income and Well-being: An Empirical Analysis of the Comparison Income Effect", Journal of Public Economics, 895-6,: 997-1019.

Frank, R. H. (1985). Choosing the right pond: Human Behavior and the Quest for Status. New York: Oxford

University Press. Frank, R. 2005, "Does absolute income matter?", in Bruni and Porta eds, "Economics and Happiness: Framing the Analysis", Oxford University Press, forthcoming.

Frey, B. S. and A. Stutzer, 2002, Happiness and Economics. How the Economy and Institutions Affect Well-being, Princeton University Press, Princeton, New Jersey.

Frey, B. S. and Stutzer, A., 2002a, Happiness and Economics. How The Economy and Institutions Affect Well-Being, Princeton University Press, Princeton, New Jersey.

Frey, B.S., Stutzer, A., 2006, "Does Marriage Make People Happy or Do Happy People Get Married?" Journal of Socio-Economics 352, 326-347.

Frijters, P., Beatton, T. (2008). The mystery of the U-shaped relationship between happiness and age, National Centre for Econometric Research Working Paper Series No.26. 
Frijters, P., Geishecker, I., Shields, M.A. and Haisken-DeNew, J.P. 2006,. "Can the Large Swings in Russian Life Satisfaction Be Explained by Ups And Downs in Real Incomes? Scandinavian Journal of Economics, forthcoming.

Frijters, P., Shields, M.A., and Haisken-DeNew, J.P. 2004a, "Money Does Matter! Evidence from Increasing Real Incomes in East Germany Following Reunification". American Economic Review, vol. 94, pp. 730-741.

Frijters, P., Shields, M.A., and Haisken-DeNew, J.P. 2004b,. "Changes in the Pattern and Determinants of Life Satisfaction in Germany Following Reunification". Journal of Human Resources, vol. 39, pp. 649-674.

Gardner J, Oswald A. "Does Money Buy Happiness? A Longitudinal Study Using Data on Windfalls.", University of Warwick Working Paper; 2001.

Gardner J, Oswald AJ., 2006, “Do Divorcing Couples Become Happier by Breaking Up?” Journal of the Royal Statistical Society Series A, 2006; 169; 319-336

Gardner J, Oswald, A., 2004, "How Is Mortality Affected by Money, Marriage and Stress?", Journal of Health Economics 2004; 23; 1181-1207.

Graham, C. and Pettinato, S., 2002, Happiness and Hardship: Opportunity and Insecurity in New Market Economies. Washington, D.C.: The Brookings Institution Press.

Hagenaars, A., K. de Vos and M.A. Zaidi (1994), Poverty Statistics in the Late 1980s: Research Based on Micro-data, Office for Official Publications of the European Communities. Luxembourg.

Hagerty, M.R., and Veenhoven, R., 2003, "Wealth and Happiness Revisited: Growing Wealth Of Nations Does Go With Greater Happiness" Social Indicators Research, vol. 64, 2003, pp. 1-27

Hayo, B. 2004,. Happiness in Eastern Europe. Mimeo, Philipps University Marburg, Number $12 / 2004$.

Hayo, B., and Wolfgang, S., 2003, "Subjective Economic Well-being in Eastern Europe," Journal of Economic Psychology, Elsevier, vol. 243, pages 329-348, June.

Helliwell, J. F. 2003, "How's life? Combining Individual and National Variables to Explain Subjective Well-Being." Economic Modelling, 20, 331-360.

Hirschman, A. (1973): "The Changing Tolerance for Income Inequality in the Course of Economic Development", Quarterly Journal of Economics, 87, 544-566.

Kahneman D. and A.B. Krueger 2006, "Developments in the Measurement of Subjective WellBeing”, Journal of Economic Perspectives, 20, 1; Pp. 3-24

Layard, R. 2005, Happiness: Lessons From a New Science, New York and London: Penguin.

Layard, R. 2005a, "Rethinking public economics: The Implications of Rivalry and Habit", in L. Bruni and P.L. Porta eds, Economics and Happiness: Reality and Paradoxes, Oxford: Oxford University Press.

Maddison, D., and Rehdanz, K., 2005, "The Amenity Value Of Climate to Households in Germany," Working Papers FNU-39, Research unit Sustainability and Global Change, Hamburg University

McBride, M., 2007, "Why Churches Need Free-riders: Religious Capital Formation and Religious Group Survival," Working Papers 060722, University of California-Irvine, Department of Economics.

Ratha, D., 2003, "Workers' Remittances: An Important and Stable Source of External Development Finance," p. 158. Pp. 157-175 in: Global Development Finance 2003: Striving for Stability in Development Finance, by The World Bank. 2003. Washington, D. C. 
Ravallion, M. and Lokshin, M., 2001, "Identifying Welfare Effects From Subjective Questions." Economica, Vol 68, pp. 335-357.

Ravallion M., Lokshin M. (2002a), "Self-rated economic welfare in Russia", European Economic Review 46, pp. 1453-1473.

Sanfey, P., and Teksoz, U., 2007, "Does Transition Make you Happy?," The Economics of Transition, The European Bank for Reconstruction and Development, vol. 15, pages 707-731, October

Schor, J. (1991), The Overworked American: The Unexpected Decline of Leisure in America, Basic Books, New York.

Scitowsky, T. 1976, The Joyless Economy: An Enquiry into Human Satisfaction and Consumer Dissatisfaction. New York, Oxford University Press

Schwarze J. (2003), "Using panel data on income satisfaction to estimate equivalence scale elasticity", Review of Income and Wealth, Vol. 49 pp.359 - 372

Senik, C., 2004. "Relativizing Relative Income," DELTA Working Papers 2004-17, DELTA

Stevenson, B., and Wolfers, J.,2008, Economic Growth and Subjective Well-Being: Reassessing the Easterlin Paradox

Stutzer, A. 2004,. "The Role of Income Aspirations in Individual Happiness", Journal of Economic Behavior and Organization, vol. 54, pp. 89-109.

Veenhoven, R. 1993, Happiness in Nations: Subjective Appreciation of Life in 56 Nations 19461992, Rotterdam, RISBO -Erasmus University Rotterdam.

World Bank, 2003, Albania Poverty Assessment, Washington DC. . 
Table 1 Taxonomy of the more relevant subgroups based on yearly changes in household income and life satisfaction

Weak frustrated achievement

\begin{tabular}{l|cc}
\hline & Higher & Lower or Equal \\
& Financial Satisfaction & Financial Satisfaction \\
\hline Higher real household income & SA & FA \\
Lower or equal real & $48.01 \%$ & $44.61 \%$ \\
household income & SL & FL \\
\hline Sourc: & $30.49 \%$ & $31.13 \%$ \\
\hline
\end{tabular}

Source: Authors' calculations on Albania LSMS (2002/2003)

Strong frustrated achievement

\begin{tabular}{l|cc}
\hline & $\begin{array}{c}\text { Higher or Equal } \\
\text { Financial Satisfaction }\end{array}$ & $\begin{array}{c}\text { Lower } \\
\text { Financial Satisfaction }\end{array}$ \\
\hline Higher real household income & SA & FA \\
Lower or equal real & $14.57 \%$ & $11.17 \%$ \\
household income & SL & FL \\
\hline
\end{tabular}

Source: Authors' calculations on Albania LSMS (2002/2003) 
Table 2 Sample descriptive Statistics (2002).

\begin{tabular}{|c|c|c|c|c|c|}
\hline & Unit & Mean & Std. Dev. & Min & Max \\
\hline \multicolumn{6}{|l|}{ Individual Characteristics } \\
\hline Dummy for Male & $\%$ & 55.6 & 49.7 & 0 & 100 \\
\hline Age in years & $\mathrm{Nb}$. & 48.4 & 13.8 & 18 & 91 \\
\hline Dummy Individual's age $0-20$ & $\%$ & 0.3 & 5.7 & 0 & 100 \\
\hline Dummy Individual's age $20-40$ & $\%$ & 28.2 & 45.0 & 0 & 100 \\
\hline Dummy Individual's age $40-60$ & $\%$ & 47.6 & 50.0 & 0 & 100 \\
\hline Dummy Individual's age $60-80$ & $\%$ & 22.9 & 42.0 & 0 & 100 \\
\hline Dummy Individual's age 80 above & $\%$ & 0.8 & 8.7 & 0 & 100 \\
\hline Size of the household & $\mathrm{Nb}$. & 4.2 & 1.8 & 1 & 13 \\
\hline Years of education & years & 9.3 & 3.6 & 0 & 19 \\
\hline Dummy for married & $\%$ & 87.0 & 33.7 & 0 & 100 \\
\hline Dummy for divorced & $\%$ & 0.9 & 9.4 & 0 & 100 \\
\hline Dummy for living together & $\%$ & 0.1 & 3.6 & 0 & 100 \\
\hline Dummy for widow & $\%$ & 10.0 & 30.0 & 0 & 100 \\
\hline Dummy for single & $\%$ & 2.0 & 14.0 & 0 & 100 \\
\hline Dummy for religion: Muslim & $\%$ & 75.4 & 43.1 & 0 & 100 \\
\hline Dummy for religion: Orthodox & $\%$ & 12.9 & 33.5 & 0 & 100 \\
\hline Dummy for religion: Catholic & $\%$ & 8.7 & 28.1 & 0 & 100 \\
\hline Dummy for religion: Bektashian & $\%$ & 2.5 & 15.6 & 0 & 100 \\
\hline \multicolumn{6}{|l|}{ Health } \\
\hline Dummy: visited public ambulatory in last month in 2002 & $\%$ & 0.2 & 0.4 & 0 & 1 \\
\hline Number of visit to public ambulatory in last month in 2002 & $\mathrm{Nb}$. & 1.6 & 1.3 & 1 & 10 \\
\hline $\begin{array}{l}\text { Costs associated with outpatient visits to public ambulatory in } \\
2002\end{array}$ & Lek & 263.6 & 742.5 & 0 & 10000 \\
\hline $\begin{array}{l}\text { Value of gifts made to medical staff of public ambulatory in } \\
2002\end{array}$ & Lek & 125.2 & 326.3 & 0 & 3000 \\
\hline \multicolumn{6}{|l|}{ Migration } \\
\hline Dummy ever migrated since 1997 & $\%$ & 7.1 & 25.7 & 0 & 100 \\
\hline Nb. of months migrated since 1997 & $\mathrm{Nb}$. & 0.9 & 4.6 & 0 & 60 \\
\hline Dummy Individual migrated in Greece between 1997 and 2001 & $\%$ & 5.3 & 22.5 & 0 & 100 \\
\hline Dummy Individual migrated in Italy between 1997 and 2001 & $\%$ & 1.6 & 12.6 & 0 & 100 \\
\hline \multicolumn{6}{|l|}{ Services availability } \\
\hline Distance in minutes from nearest primary school & $\mathrm{mn}$ & 12.6 & 11.9 & 1 & 90 \\
\hline Distance in minutes from nearest ambulatory doctor & $\mathrm{mn}$ & 18.2 & 17.5 & 1 & 96 \\
\hline Distance in minutes from nearest bus stop & $\mathrm{mn}$ & 16.6 & 18.9 & 1 & 99 \\
\hline \multicolumn{6}{|l|}{ Assets } \\
\hline Dummy has: colour tv & $\%$ & 87.9 & 32.6 & 0 & 100 \\
\hline Dummy has: tv B\&W & $\%$ & 9.9 & 29.9 & 0 & 100 \\
\hline Dummy has: fridge & $\%$ & 83.9 & 36.8 & 0 & 100 \\
\hline Dummy has: stove & $\%$ & 60.7 & 48.9 & 0 & 100 \\
\hline Dummy has: sewage & $\%$ & 16.4 & 37.0 & 0 & 100 \\
\hline Dummy has: computer & $\%$ & 2.5 & 15.6 & 0 & 100 \\
\hline Dummy has: bike & $\%$ & 16.6 & 37.2 & 0 & 100 \\
\hline Dummy has: motorbike & $\%$ & 3.8 & 19.1 & 0 & 100 \\
\hline Dummy has: car & $\%$ & 8.5 & 27.9 & 0 & 100 \\
\hline Dummy has: truck & $\%$ & 2.6 & 16.0 & 0 & 100 \\
\hline \multicolumn{6}{|l|}{ Income and Economic Status } \\
\hline Economic Status, 10 step ladder $1=$ poorest $-10=$ richest & 1 to 10 & 3.7 & 1.7 & 1 & 10 \\
\hline $\begin{array}{l}\text { Per adult equivalent Real HH income per month in New Lek in } \\
2002\end{array}$ & Lek & 19974.1 & 42609.4 & -32882.6 & 770241.6 \\
\hline Share of income from wage in 2002 & $\%$ & 45.8 & 46.0 & 0 & 100 \\
\hline Share of income from social assistance in 2002 & $\%$ & 45.5 & 44.2 & 0 & 100 \\
\hline Share of income from remittances in 2002 & $\%$ & 8.7 & 23.1 & 0 & 100 \\
\hline
\end{tabular}


Table 2 Sample descriptive Statistics (2002) - (follows).

\begin{tabular}{|c|c|c|c|c|c|}
\hline & Unit & Mean & Std. Dev. & "Min & Max \\
\hline $\begin{array}{l}\text { Dummy is household income below the mean district income in } \\
2002\end{array}$ & $\%$ & 63.7 & 48.1 & 0 & 100 \\
\hline Dummy Employment status: Full-time Emp & $\%$ & $43 \%$ & $49 \%$ & 0 & 1 \\
\hline Dummy Employment status: Part-time Emp & $\%$ & $15 \%$ & $36 \%$ & 0 & 1 \\
\hline Dummy Employment status: Student & $\%$ & $0 \%$ & $6 \%$ & 0 & 1 \\
\hline Dummy Employment status: Retired & $\%$ & $19 \%$ & $40 \%$ & 0 & 1 \\
\hline Dummy Employment status: Looking after house/family & $\%$ & $8 \%$ & $27 \%$ & 0 & 1 \\
\hline Dummy Employment status: Handicapped & $\%$ & $3 \%$ & $17 \%$ & 0 & 1 \\
\hline Dummy Employment status: Not employed & $\%$ & $8 \%$ & $27 \%$ & 0 & 1 \\
\hline Dummy Employment status: ILO definition unemployed & $\%$ & $3 \%$ & $18 \%$ & 0 & 1 \\
\hline Dummy Frustrated Achievers Weak Assumption & $\%$ & $44.6 \%$ & $49.7 \%$ & 0 & 1 \\
\hline Dummy Frustrated Losers Weak Assumption & $\%$ & $31.1 \%$ & $46.3 \%$ & 0 & 1 \\
\hline Dummy Satisfied Achievers Weak Assumption & $\%$ & $48.0 \%$ & $50.0 \%$ & 0 & 1 \\
\hline Dummy Satisfied Looser Weak Assumption & $\%$ & $30.5 \%$ & $46.1 \%$ & 0 & 1 \\
\hline Dummy Satisfied Achievers Strong Assumption & $\%$ & $14.6 \%$ & $35.3 \%$ & 0 & 1 \\
\hline Dummy Satisfied Looser Strong Assumption & $\%$ & $9.7 \%$ & $29.6 \%$ & 0 & 1 \\
\hline Dummy Frustrated Achievers Strong Assumption & $\%$ & $11.2 \%$ & $31.5 \%$ & 0 & 1 \\
\hline Dummy Frustrated Losers Strong Assumption & $\%$ & $10.3 \%$ & $30.4 \%$ & 0 & 1 \\
\hline
\end{tabular}

Source: Authors' calculations on Albania LSMS (2002/2003) 
Table 3a. Summary statistics for Strongly Frustrated Achievers,:

LSMS Albania 2002

\begin{tabular}{|c|c|c|c|c|}
\hline Variables & Unit & NFA Strong & FA Strong & Total \\
\hline Share of households & $\%$ & 88.83 & 11.17 & 100 \\
\hline \multicolumn{5}{|l|}{ Individual Characteristics } \\
\hline Dummy for Male & $\%$ & 54.91 & 60.92 & 55.58 \\
\hline Head's age in years & years. & $48.03 * * *$ & $51.08 * * *$ & 48.37 \\
\hline Dummy Individual's age $0-20$ & $\%$ & 0.36 & 0 & 0.32 \\
\hline Dummy Individual's age 20-40 & $\%$ & 28.9 & 22.99 & 28.24 \\
\hline Dummy Individual's age 40-60 & $\%$ & 48.12 & 43.68 & 47.63 \\
\hline Dummy Individual's age 60-80 & $\%$ & $21.60 * * *$ & $33.33 * * *$ & 22.91 \\
\hline Dummy Individual's age 80 above & $\%$ & 0.87 & 0 & 0.77 \\
\hline Size of the household & $\mathrm{Nb}$. & 4.2 & 4.1 & 4.19 \\
\hline Years of education of the head & years & 9.29 & 9.46 & 9.31 \\
\hline Dummy for married & $\%$ & 86.49 & 90.8 & 86.97 \\
\hline Dummy for divorced & $\%$ & 1.01 & 0 & 0.9 \\
\hline Dummy for living together & $\%$ & 0.14 & 0 & 0.13 \\
\hline Dummy for widow & $\%$ & 10.26 & 8.05 & 10.01 \\
\hline Dummy for single & $\%$ & 2.1 & 1.15 & 1.99 \\
\hline Dummy for religion: Muslim & $\%$ & 75 & 78.74 & 75.42 \\
\hline Dummy for religion: Orthodox & $\%$ & 13.01 & 12.07 & 12.9 \\
\hline Dummy for religion: Catholic & $\%$ & 8.96 & 6.32 & 8.66 \\
\hline Dummy for religion: Bektashian & $\%$ & 2.67 & 1.15 & 2.5 \\
\hline \multicolumn{5}{|l|}{ Health } \\
\hline Dummy: visited public ambulatory in last month in 2002 & $\%$ & 0.21 & 0.19 & 0.21 \\
\hline Number of visit to public ambulatory in last month in 2002 & $\mathrm{Nb}$. & 0.33 & 0.27 & 0.33 \\
\hline Costs associated with outpatient visits to public ambulatory in 2002 & Lek & 0.01 & 0 & 0.01 \\
\hline Value of gifts made to medical staff of public ambulatory in 2002 & Lek & 0 & 0 & 0 \\
\hline \multicolumn{5}{|l|}{ Migration } \\
\hline Dummy ever migrated since 1997 & $\%$ & 7.37 & 5.17 & 7.12 \\
\hline Nb. of months migrated since 1997 & $\mathrm{Nb}$. & 0.88 & 0.78 & 0.87 \\
\hline Dummy Individual migrated in Greece between 1997 and 2001 & $\%$ & 5.64 & 2.87 & 5.33 \\
\hline Dummy Individual migrated in Italy between 1997 and 2001 & $\%$ & 1.52 & 2.3 & 1.6 \\
\hline \multicolumn{5}{|l|}{ Services availability } \\
\hline Distance in minutes from nearest primary school & $\mathrm{mn}$ & 0.13 & 0.12 & 0.13 \\
\hline Distance in minutes from nearest ambulatory doctor & $\mathrm{mn}$ & 0.18 & 0.2 & 0.18 \\
\hline Distance in minutes from nearest bus stop & $\mathrm{mn}$ & 0.17 & 0.17 & 0.17 \\
\hline \multicolumn{5}{|l|}{ Assets } \\
\hline Dummy has: colour tv & $\%$ & $87.43^{*}$ & $91.95^{*}$ & 87.93 \\
\hline Dummy has: tv B\&W & $\%$ & 9.97 & 9.2 & 9.88 \\
\hline Dummy has: fridge & $\%$ & 83.38 & 87.93 & 83.89 \\
\hline Dummy has: stove & $\%$ & 60.62 & 61.49 & 60.72 \\
\hline Dummy has: sewage & $\%$ & $15.61 * *$ & $22.41 * *$ & 16.37 \\
\hline Dummy has: computer & $\%$ & 2.31 & 4.02 & 2.5 \\
\hline Dummy has: bike & $\%$ & 16.55 & 17.24 & 16.62 \\
\hline Dummy has: motorbike & $\%$ & 3.97 & 2.3 & 3.79 \\
\hline Dummy has: car & $\%$ & 8.45 & 8.62 & 8.47 \\
\hline Dummy has: truck & $\%$ & 2.82 & 1.15 & 2.63 \\
\hline \multicolumn{5}{|l|}{ Income and Economic Status } \\
\hline Economic Status, 10 step ladder $1=$ poorest $-10=$ richest & $\begin{array}{c}1 \\
\text { to } 10\end{array}$ & $3.66 * * *$ & $4.40 * * *$ & 3.74 \\
\hline Total HH income per month in New Lek & Lek & $21642.69 *$ & $17054.38^{*}$ & 21147.93 \\
\hline Share of income from wage in 2002 & $\%$ & 46.08 & 43.5 & 45.78 \\
\hline
\end{tabular}


Table 3a. Summary statistics for Strongly Frustrated Achievers,:

LSMS Albania 2002 - (follows)

\begin{tabular}{lcccc}
\hline \multicolumn{1}{c}{ Variables } & Unit & NFA Strong & FA Strong & Total \\
\hline Share of income from social assistance in 2002 & $\%$ & $37.67 *$ & $44.57 *$ & 38.44 \\
Share of income from remittances in 2002 & $\%$ & 7.57 & 5.44 & 7.33 \\
Dummy is household income below the mean district income in 2002 & $\%$ & $62.93 *$ & $69.54 *$ & 63.67 \\
Dummy Employment status: Full-time Emp & $\%$ & 42 & 47 & 43 \\
Dummy Employment status: Part-time Emp & $\%$ & 15 & 12 & 15 \\
Dummy Employment status: Student & $\%$ & 0 & 1 & 0 \\
Dummy Employment status: Retired & $\%$ & $19 *$ & $25^{*}$ & 19 \\
Dummy Employment status: Looking after house/family & $\%$ & 8 & 6 & 8 \\
Dummy Employment status: Handicapped & $\%$ & 3 & 2 & 3 \\
Dummy Employment status: Not employed & $\%$ & $8 * *$ & $4 * *$ & 8 \\
Dummy Employment status: ILO definition unemployed & $\%$ & 3 & 3 & 3 \\
$*$ significant at 10\%; ** significant at 5\%; *** significant at 1\% & & & & \\
\hline \hline
\end{tabular}

Source: Authors' calculations on Albania LSMS (2002/2003) 
Table 3b. Summary of statistics for Weakly Frustrated Achievers

LSMS Albania 2002

\begin{tabular}{|c|c|c|c|c|}
\hline Variables & Unit & NFA weak & FA weak & Total \\
\hline Share of households & $\%$ & 55.39 & 44.61 & 100 \\
\hline \multicolumn{5}{|l|}{ Individual Characteristics } \\
\hline Dummy for Male & $\%$ & 54.69 & 56.69 & 55.58 \\
\hline Head's age in years & years. & $47.22 * * *$ & $49.79 * * *$ & 48.37 \\
\hline Dummy Individual's age $0-20$ & $\%$ & $0.58 * *$ & $0.00 * *$ & 0.32 \\
\hline Dummy Individual's age $20-40$ & $\%$ & $30.13 *$ & $25.90 *$ & 28.24 \\
\hline Dummy Individual's age 40-60 & $\%$ & 48.44 & 46.62 & 47.63 \\
\hline Dummy Individual's age 60-80 & $\%$ & $19.70 * * *$ & $26.91 * * *$ & 22.91 \\
\hline Dummy Individual's age 80 above & $\%$ & $1.16^{*}$ & $0.29 *$ & 0.77 \\
\hline Size of the household & $\mathrm{Nb}$. & 4.17 & 4.21 & 4.19 \\
\hline Years of education of the head & years & $9.44 *$ & $9.14 *$ & 9.31 \\
\hline Dummy for married & $\%$ & 86.56 & 87.48 & 86.97 \\
\hline Dummy for divorced & $\%$ & 0.93 & 0.86 & 0.9 \\
\hline Dummy for living together & $\%$ & 0.23 & 0 & 0.13 \\
\hline Dummy for widow & $\%$ & 10.54 & 9.35 & 10.01 \\
\hline Dummy for single & $\%$ & 1.74 & 2.3 & 1.99 \\
\hline Dummy for religion: Muslim & $\%$ & 74.39 & 76.69 & 75.42 \\
\hline Dummy for religion: Orthodox & $\%$ & 12.98 & 12.81 & 12.9 \\
\hline Dummy for religion: Catholic & $\%$ & 9.62 & 7.48 & 8.66 \\
\hline Dummy for religion: Bektashian & $\%$ & 2.67 & 2.3 & 2.5 \\
\hline \multicolumn{5}{|l|}{ Health } \\
\hline Dummy: visited public ambulatory in last month in 2002 & $\%$ & 0.21 & 0.2 & 0.21 \\
\hline Number of visit to public ambulatory in last month in 2002 & $\mathrm{Nb}$. & 0.34 & 0.31 & 0.33 \\
\hline Costs associated with outpatient visits to public ambulatory in 2002 & Lek & 0 & 0.01 & 0.01 \\
\hline Value of gifts made to medical staff of public ambulatory in 2002 & Lek & 0 & 0 & 0 \\
\hline \multicolumn{5}{|l|}{ Migration } \\
\hline Dummy ever migrated since 1997 & $\%$ & $8.81 * * *$ & $5.04 * * *$ & 7.12 \\
\hline Nb. of months migrated since 1997 & $\mathrm{Nb}$. & $1.05^{*}$ & $0.65 *$ & 0.87 \\
\hline Dummy Individual migrated in Greece between 1997 and 2001 & $\%$ & $6.49 * *$ & $3.88 * *$ & 5.33 \\
\hline Dummy Individual migrated in Italy between 1997 and 2001 & $\%$ & 1.85 & 1.29 & 1.6 \\
\hline \multicolumn{5}{|l|}{ Services availability } \\
\hline Distance in minutes from nearest primary school & $\mathrm{mn}$ & 0.13 & 0.13 & 0.13 \\
\hline Distance in minutes from nearest ambulatory doctor & $\mathrm{mn}$ & 0.18 & 0.19 & 0.18 \\
\hline Distance in minutes from nearest bus stop & $\mathrm{mn}$ & 0.17 & 0.17 & 0.17 \\
\hline \multicolumn{5}{|l|}{ Assets } \\
\hline Dummy has: color tv & $\%$ & 88.99 & 86.62 & 87.93 \\
\hline Dummy has: tv B\&W & $\%$ & 9.27 & 10.65 & 9.88 \\
\hline Dummy has: fridge & $\%$ & 84.59 & 83.02 & 83.89 \\
\hline Dummy has: stove & $\%$ & 62.34 & 58.71 & 60.72 \\
\hline Dummy has: sewage & $\%$ & 15.41 & 17.55 & 16.37 \\
\hline Dummy has: computer & $\%$ & 2.32 & 2.73 & 2.5 \\
\hline Dummy has: bike & $\%$ & 17.5 & 15.54 & 16.62 \\
\hline Dummy has: motorbike & $\%$ & 4.29 & 3.17 & 3.79 \\
\hline Dummy has: car & $\%$ & 9.15 & 7.63 & 8.47 \\
\hline Dummy has: truck & $\%$ & 3.13 & 2.01 & 2.63 \\
\hline \multicolumn{5}{|l|}{ Income and Economic Status } \\
\hline Economic Status, 10 step ladder $1=$ poorest $-10=$ richest & 1 to10 & 3.69 & 3.81 & 3.74 \\
\hline Total HH income per month in New Lek & Lek & $24097.22 * * *$ & $17208.18 * * *$ & 21147.93 \\
\hline Share of income from wage in 2002 & $\%$ & $49.80 * * *$ & $41.18 * * *$ & 45.78 \\
\hline Share of income from social assistance in 2002 & $\%$ & $31.82 * * *$ & $46.65 * * *$ & 38.44 \\
\hline
\end{tabular}


Table 3b. Summary of statistics for Weakly Frustrated Achievers

LSMS Albania 2002 - (follows)

Share of income from remittances in 2002

$\begin{array}{lccc}\% & 8.95 * * * & 5.31 * * * & 7.33 \\ \% & 58.98^{* * *} & 69.50^{* * *} & 63.67 \\ \% & 44 & 41 & 43 \\ \% & 16 & 14 & 15 \\ \% & 18 * * & 22 * * & 19 \\ \% & 8 & 8 & 8 \\ \% & 3 & 3 & 3 \\ \% & 9 & 7 & 8 \\ \% & 2 * * & 4 * * & 3\end{array}$

Dummy is household income below the mean district income in 2002

Dummy Employment status: Full-time Emp

Dummy Employment status: Part-time Emp

Dummy Employment status: Retired

Dummy Employment status: Looking after house/family

Dummy Employment status: Handicapped

Dummy Employment status: Not employed

Dummy Employment status: ILO definition unemployed

* significant at $10 \%$;* significant at $5 \%$; ** significant at $1 \%$

Source: Authors' calculations on Albania LSMS (2002/2003) 
Figure 1 Distribution of log changes in household income for (weakly) frustrated and non frustrated achievers
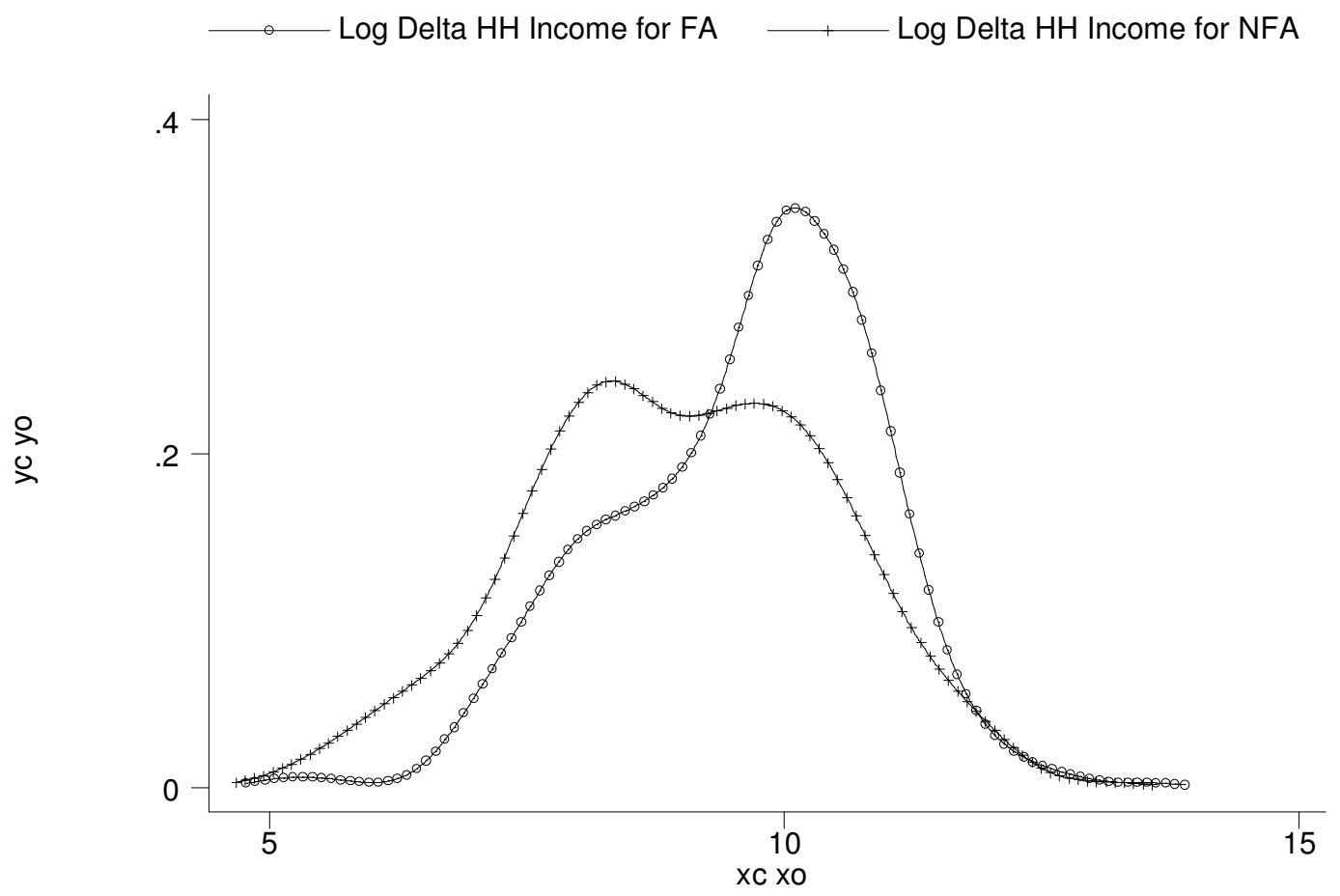

Source: Authors' calculations on Albania LSMS (2002/2003) 
Table 4. The determinants of frustrated achievement

\begin{tabular}{|c|c|c|c|c|}
\hline & $\begin{array}{c}1) \\
\text { Probit on Weak } \\
\text { Assumption of FA }\end{array}$ & $\begin{array}{c}(2) \\
\text { Probit on Weak } \\
\text { Assumption of FA }\end{array}$ & $\begin{array}{c}(3) \\
\text { Probit on Weak } \\
\text { Assumption of FA }\end{array}$ & $\begin{array}{c}\text { (4) } \\
\text { Probit on Weak } \\
\text { Assumption of FA }\end{array}$ \\
\hline $\begin{array}{l}\text { Per adult equivalent Real HH income } \\
\text { per month in New Lek in } 2002\end{array}$ & $\begin{array}{c}-0.036 * * \\
(2.46)\end{array}$ & $\begin{array}{c}-0.034 * * \\
(2.32)\end{array}$ & & \\
\hline $\begin{array}{l}\text { Log equivalent Real HH income per } \\
\text { month in New Lek in } 2002\end{array}$ & & & $\begin{array}{c}-0.072 * \\
(1.86)\end{array}$ & $\begin{array}{l}-0.060 \\
(1.54)\end{array}$ \\
\hline $\begin{array}{l}\text { Share of income from social assistance } \\
\text { in } 2002\end{array}$ & $\begin{array}{l}0.190 * * * \\
(5.24)\end{array}$ & $\begin{array}{l}0.197 * * * \\
\quad(5.45)\end{array}$ & $\begin{array}{l}0.188 * * * \\
(5.09)\end{array}$ & $\begin{array}{c}0.198 * * * \\
(5.36)\end{array}$ \\
\hline $\begin{array}{l}\text { Share of income from remittances in } \\
2002\end{array}$ & $\begin{array}{c}-0.245^{* * * *} \\
(3.46)\end{array}$ & & $\begin{array}{c}-0.240 * * * \\
(3.39)\end{array}$ & \\
\hline $\begin{array}{l}\text { Dummy if share of remittance is lower } \\
\text { than } 25 \% \text { of total income }\end{array}$ & & $\begin{array}{c}-0.204 * * * \\
(3.64)\end{array}$ & & $\begin{array}{c}-0.201 * * * \\
(3.58)\end{array}$ \\
\hline $\begin{array}{l}\text { Dummy if share of remittance is larger } \\
\text { than } 25 \% \text { of total income }\end{array}$ & & $\begin{array}{c}-0.190 * * * \\
(4.03)\end{array}$ & & $\begin{array}{c}-0.186^{* * *} \\
(3.95)\end{array}$ \\
\hline $\begin{array}{l}\text { Dummy Employment status: ILO } \\
\text { definition unemployed in } 2002\end{array}$ & $\begin{array}{c}0.219 * * * \\
(2.93)\end{array}$ & $\begin{array}{c}0.224 * * * \\
(2.98)\end{array}$ & $\begin{array}{c}0.218 * * * \\
(2.92)\end{array}$ & $\begin{array}{c}0.223 * * * \\
(2.97)\end{array}$ \\
\hline $\begin{array}{l}\text { Economic Status, } 10 \text { step ladder } \\
1=\text { poorest }-10=\text { richest }\end{array}$ & $\begin{array}{c}0.026 * * * \\
(2.96)\end{array}$ & $\begin{array}{c}0.026 * * * \\
(2.97)\end{array}$ & $\begin{array}{c}0.024 * * * \\
(2.73)\end{array}$ & $\begin{array}{c}0.024 * * * \\
(2.70)\end{array}$ \\
\hline Year 2002: Age in years & $\begin{array}{c}0.003 * * * \\
(2.64)\end{array}$ & $\begin{array}{l}0.004 * * * \\
(3.25)\end{array}$ & $\begin{array}{l}0.003 * * * \\
(2.73)\end{array}$ & $\begin{array}{l}0.004 * * * \\
\quad(3.30)\end{array}$ \\
\hline Year 2002: Years of education & $\begin{array}{l}-0.002 \\
(0.35)\end{array}$ & $\begin{array}{r}-0.002 \\
(0.43)\end{array}$ & $\begin{array}{l}-0.002 \\
(0.41)\end{array}$ & $\begin{array}{c}-0.002 \\
(0.53)\end{array}$ \\
\hline Year 2002: Dummy for married & $\begin{array}{l}0.046 \\
(0.33)\end{array}$ & $\begin{array}{l}0.037 \\
(0.26)\end{array}$ & $\begin{array}{l}0.047 \\
(0.34)\end{array}$ & $\begin{array}{l}0.038 \\
(0.27)\end{array}$ \\
\hline Year 2002: Dummy for widow & $\begin{array}{l}-0.070 \\
(0.48)\end{array}$ & $\begin{array}{l}-0.064 \\
(0.44)\end{array}$ & $\begin{array}{l}-0.070 \\
(0.48)\end{array}$ & $\begin{array}{l}-0.064 \\
(0.44)\end{array}$ \\
\hline Year 2002: Dummy for single & $\begin{array}{l}0.099 \\
(0.58)\end{array}$ & $\begin{array}{l}0.089 \\
(0.52)\end{array}$ & $\begin{array}{l}0.103 \\
(0.61)\end{array}$ & $\begin{array}{l}0.094 \\
(0.55)\end{array}$ \\
\hline $\begin{array}{l}\text { Year 2002: Dummy for religion: } \\
\text { Muslim }\end{array}$ & $\begin{array}{l}-0.029 \\
(0.32)\end{array}$ & $\begin{array}{l}-0.023 \\
(0.25)\end{array}$ & $\begin{array}{l}-0.022 \\
(0.25)\end{array}$ & $\begin{array}{l}-0.016 \\
(0.18)\end{array}$ \\
\hline $\begin{array}{l}\text { Year 2002: Dummy for religion: } \\
\text { Orthodox }\end{array}$ & $\begin{array}{l}-0.044 \\
(0.47)\end{array}$ & $\begin{array}{l}-0.035 \\
(0.37)\end{array}$ & $\begin{array}{l}-0.039 \\
(0.42)\end{array}$ & $\begin{array}{l}-0.031 \\
(0.33)\end{array}$ \\
\hline $\begin{array}{l}\text { Year 2002: Dummy for religion: } \\
\text { Catholic }\end{array}$ & $\begin{array}{c}-0.206 * * \\
(2.03)\end{array}$ & $\begin{array}{c}-0.202^{* *} \\
(1.98)\end{array}$ & $\begin{array}{c}-0.201 * * \\
(1.98)\end{array}$ & $\begin{array}{c}-0.197 * \\
(1.93)\end{array}$ \\
\hline $\begin{array}{l}\text { Number of visit to public ambulatory } \\
\text { in last month in } 2002\end{array}$ & $\begin{array}{l}-0.029 \\
(1.57)\end{array}$ & $\begin{array}{l}-0.027 \\
(1.45)\end{array}$ & $\begin{array}{l}-0.029 \\
(1.57)\end{array}$ & $\begin{array}{l}-0.027 \\
(1.47)\end{array}$ \\
\hline $\begin{array}{l}\text { Costs associated with outpatient visits } \\
\text { to public ambulatory in } 2002\end{array}$ & $\begin{array}{c}0.956^{*} \\
(1.96)\end{array}$ & $\begin{array}{r}0.895^{*} \\
(1.81)\end{array}$ & $\begin{array}{c}0.948 * \\
(1.96)\end{array}$ & $\begin{array}{l}0.893^{*} \\
(1.82)\end{array}$ \\
\hline $\begin{array}{l}\text { Value of gifts made to medical staff of } \\
\text { public ambulatory in } 2002\end{array}$ & $\begin{array}{l}-0.312 \\
(0.32)\end{array}$ & $\begin{array}{l}-0.162 \\
(0.17)\end{array}$ & $\begin{array}{l}-0.299 \\
(0.30)\end{array}$ & $\begin{array}{l}-0.150 \\
(0.16)\end{array}$ \\
\hline Dummy ever migrated since 1997 & $\begin{array}{c}-0.321 * * \\
(1.99)\end{array}$ & $\begin{array}{c}-0.317^{*} \\
(1.96)\end{array}$ & $\begin{array}{c}-0.320 * * \\
(1.98)\end{array}$ & $\begin{array}{c}-0.315^{*} \\
(1.94)\end{array}$ \\
\hline Nb. of months migrated since 1997 & $\begin{array}{l}0.001 \\
(0.15)\end{array}$ & $\begin{array}{l}0.000 \\
(0.03)\end{array}$ & $\begin{array}{l}0.000 \\
(0.11)\end{array}$ & $\begin{array}{l}-0.000 \\
(0.00)\end{array}$ \\
\hline $\begin{array}{l}\text { Dummy Individual migrated in Greece } \\
\text { between } 1997 \text { and } 2001\end{array}$ & $\begin{array}{l}0.207 \\
(1.06)\end{array}$ & $\begin{array}{l}0.206 \\
(1.06)\end{array}$ & $\begin{array}{l}0.207 \\
(1.06)\end{array}$ & $\begin{array}{l}0.205 \\
(1.05)\end{array}$ \\
\hline $\begin{array}{l}\text { Dummy Individual migrated in Italy } \\
\text { between } 1997 \text { and } 2001\end{array}$ & $\begin{array}{l}0.192 \\
(0.99)\end{array}$ & $\begin{array}{l}0.201 \\
(1.04)\end{array}$ & $\begin{array}{l}0.194 \\
(1.00)\end{array}$ & $\begin{array}{l}0.202 \\
(1.04)\end{array}$ \\
\hline
\end{tabular}


Table 4. The determinants of frustrated achievement - (follows)

\begin{tabular}{lcccc}
\hline & $\begin{array}{c}\text { Probit on Weak } \\
\text { Assumption of FA }\end{array}$ & $\begin{array}{c}\text { Probit on Weak } \\
\text { Assumption of FA }\end{array}$ & $\begin{array}{c}\text { Probit on Weak } \\
\text { Assumption of FA }\end{array}$ & $\begin{array}{c}\text { Probit on Weak } \\
\text { Assumption of FA }\end{array}$ \\
\hline Year 2002: Distance in minutes from & -0.262 & $-0.271^{*}$ & -0.257 & $-0.264^{*}$ \\
nearest primary school & $(1.64)$ & $(1.69)$ & $(1.61)$ & $(1.65)$ \\
Year 2002: Distance in minutes from & 0.187 & 0.191 & 0.185 & 0.190 \\
nearest ambulatory doctor & $(1.58)$ & $(1.61)$ & $(1.56)$ & $(1.60)$ \\
& 0.037 & 0.034 & 0.035 & 0.032 \\
Year 2002: Distance in minutes from & $(0.39)$ & $(0.35)$ & $(0.37)$ & $(0.34)$ \\
nearest bus stop & 1556 & 1556 & 1556 & 1556 \\
Observations & -980.83 & -973.74 & -982.20 & -975.33 \\
Log likelihood & 0.08 & 0.09 & 0.08 & 0.09 \\
Pseudo R-square & & &
\end{tabular}

Source: Authors' calculations on Albania LSMS (2002/2003)

Estimated sample: achievers only (individuals which registered a non negative change in equivalised household income between 2002 and 2003). Dummies for districts estimated but not reported

Absolute value of $\mathrm{z}$ statistics in parentheses

* significant at $10 \%$; ** significant at 5\%; *** significant at $1 \%$ 
Table 5. The determinants of life satisfaction

\begin{tabular}{|c|c|c|c|c|}
\hline & $\begin{array}{c}1) \\
\text { Ordered Probit on } \\
\text { Happiness in } 2003 \\
\end{array}$ & $\begin{array}{c}\text { (2) } \\
\text { Ordered Probit on } \\
\text { Happiness in } 2003 \\
\end{array}$ & $\begin{array}{c}(3) \\
\text { Ordered Probit on } \\
\text { Happiness in } 2003 \\
\end{array}$ & $\begin{array}{c}\text { (4) } \\
\text { Ordered Probit on } \\
\text { Happiness in 2003 } \\
\end{array}$ \\
\hline $\begin{array}{l}\text { Per adult equivalent Real HH } \\
\text { income per month in New Lek in } \\
2002\end{array}$ & $\begin{array}{c}0.030 * * * \\
(3.36)\end{array}$ & $\begin{array}{c}0.030 * * * \\
(3.39)\end{array}$ & & \\
\hline $\begin{array}{l}\text { Log equivalent Real HH income } \\
\text { per month in New Lek in } 2003\end{array}$ & & & $\begin{array}{c}0.158 * * * \\
(2.77)\end{array}$ & $\begin{array}{c}0.158 * * * \\
(2.77)\end{array}$ \\
\hline $\begin{array}{l}\text { Share of income from social } \\
\text { assistance in } 2002\end{array}$ & $\begin{array}{l}0.018 \\
(0.17)\end{array}$ & $\begin{array}{l}0.013 \\
(0.13)\end{array}$ & $\begin{array}{l}0.031 \\
(0.30)\end{array}$ & $\begin{array}{l}0.025 \\
(0.24)\end{array}$ \\
\hline $\begin{array}{l}\text { Share of income from remittances } \\
\text { in } 2002\end{array}$ & $\begin{array}{c}0.441 * * \\
(2.50)\end{array}$ & & $\begin{array}{c}0.476 * * * \\
(2.69)\end{array}$ & \\
\hline $\begin{array}{l}\text { Dummy if share of remittance is } \\
\text { lower than } 25 \% \text { of total income }\end{array}$ & & $\begin{array}{l}0.097 \\
(0.60)\end{array}$ & & $\begin{array}{l}0.084 \\
(0.53)\end{array}$ \\
\hline $\begin{array}{l}\text { Dummy if share of remittance is } \\
\text { larger than } 25 \% \text { of total income }\end{array}$ & & $\begin{array}{c}0.348^{* * *} \\
(2.70)\end{array}$ & & $\begin{array}{c}0.366^{* * * *} \\
(2.84)\end{array}$ \\
\hline $\begin{array}{l}\text { Dummy Employment status: ILO } \\
\text { definition unemployed in } 2002\end{array}$ & $\begin{array}{c}-0.724 * * * \\
(2.81)\end{array}$ & $\begin{array}{c}-0.724 * * * \\
(2.82)\end{array}$ & $\begin{array}{c}-0.724 * * * \\
(2.81)\end{array}$ & $\begin{array}{c}-0.723 * * * \\
(2.81)\end{array}$ \\
\hline $\begin{array}{l}\text { Economic Status, } 10 \text { step ladder } \\
1=\text { poorest }-10=\text { richest }\end{array}$ & $\begin{array}{c}0.306^{* * * *} \\
(11.72)\end{array}$ & $\begin{array}{c}0.306^{* * *} \\
(11.73)\end{array}$ & $\begin{array}{c}0.307 * * * \\
(11.76)\end{array}$ & $\begin{array}{c}0.308 * * * \\
(11.79)\end{array}$ \\
\hline Year 2002: Age in years & $\begin{array}{l}-0.001 \\
(0.28)\end{array}$ & $\begin{array}{l}-0.002 \\
(0.45)\end{array}$ & $\begin{array}{l}-0.002 \\
(0.54)\end{array}$ & $\begin{array}{l}-0.002 \\
(0.68)\end{array}$ \\
\hline Year 2002: Years of education & $\begin{array}{c}0.035 * * * \\
(3.05)\end{array}$ & $\begin{array}{l}0.035 * * * \\
(3.05)\end{array}$ & $\begin{array}{l}0.034 * * * \\
(2.94)\end{array}$ & $\begin{array}{l}0.034 * * * \\
(2.94)\end{array}$ \\
\hline Year 2002: Dummy for married & $\begin{array}{l}-0.016 \\
(0.04)\end{array}$ & $\begin{array}{l}0.001 \\
(0.00)\end{array}$ & $\begin{array}{l}-0.104 \\
(0.09)\end{array}$ & $\begin{array}{l}-0.114 \\
(0.10)\end{array}$ \\
\hline $\begin{array}{l}\text { Year 2002: Dummy for living } \\
\text { together }\end{array}$ & $\begin{array}{l}0.066 \\
(0.05)\end{array}$ & $\begin{array}{l}0.090 \\
(0.07)\end{array}$ & & \\
\hline $\begin{array}{l}\text { Year 2002: Dummy for widow } \\
\text { Year 2002: Dummy for single }\end{array}$ & $\begin{array}{l}-0.192 \\
(0.51) \\
0.054 \\
(0.12)\end{array}$ & $\begin{array}{l}-0.182 \\
(0.49) \\
0.078 \\
(0.17)\end{array}$ & $\begin{array}{l}-0.276 \\
(0.24) \\
-0.038 \\
(0.03)\end{array}$ & $\begin{array}{l}-0.292 \\
(0.25) \\
-0.042 \\
(0.03)\end{array}$ \\
\hline $\begin{array}{l}\text { Year 2002: Dummy for religion: } \\
\text { Muslim }\end{array}$ & $\begin{array}{l}-0.108 \\
(0.43)\end{array}$ & $\begin{array}{l}-0.112 \\
(0.45)\end{array}$ & $\begin{array}{r}-0.127 \\
(0.51)\end{array}$ & $\begin{array}{r}-0.132 \\
(0.54)\end{array}$ \\
\hline $\begin{array}{l}\text { Year 2002: Dummy for religion: } \\
\text { Orthodox }\end{array}$ & $\begin{array}{l}0.050 \\
(0.19)\end{array}$ & $\begin{array}{l}0.042 \\
(0.16)\end{array}$ & $\begin{array}{l}0.017 \\
(0.06)\end{array}$ & $\begin{array}{l}0.008 \\
(0.03)\end{array}$ \\
\hline $\begin{array}{l}\text { Year 2002: Dummy for religion: } \\
\text { Catholic }\end{array}$ & $\begin{array}{l}0.390 \\
(1.29)\end{array}$ & $\begin{array}{l}0.377 \\
(1.25)\end{array}$ & $\begin{array}{l}0.374 \\
(1.24)\end{array}$ & $\begin{array}{l}0.361 \\
(1.19)\end{array}$ \\
\hline $\begin{array}{l}\text { Number of visit to public } \\
\text { ambulatory in last month in } 2002\end{array}$ & $\begin{array}{l}0.000 \\
(0.00)\end{array}$ & $\begin{array}{l}-0.003 \\
(0.05)\end{array}$ & $\begin{array}{l}-0.001 \\
(0.02)\end{array}$ & $\begin{array}{l}-0.004 \\
(0.08)\end{array}$ \\
\hline $\begin{array}{l}\text { Costs associated with outpatient } \\
\text { visits to public ambulatory in } \\
2002\end{array}$ & $\begin{array}{l}-0.469 \\
(0.48)\end{array}$ & $\begin{array}{l}-0.365 \\
(0.37)\end{array}$ & $\begin{array}{l}-0.490 \\
(0.50)\end{array}$ & $\begin{array}{l}-0.376 \\
(0.38)\end{array}$ \\
\hline $\begin{array}{l}\text { Value of gifts made to medical } \\
\text { staff of public ambulatory in } 2002\end{array}$ & $\begin{array}{r}-1.374 \\
(0.56)\end{array}$ & $\begin{array}{r}-1.402 \\
(0.57)\end{array}$ & $\begin{array}{r}-1.288 \\
(0.53)\end{array}$ & $\begin{array}{r}-1.302 \\
(0.53)\end{array}$ \\
\hline Dummy ever migrated since 1997 & $\begin{array}{l}0.705 \\
(1.59)\end{array}$ & $\begin{array}{l}0.695 \\
(1.57)\end{array}$ & $\begin{array}{l}0.684 \\
(1.55)\end{array}$ & $\begin{array}{l}0.674 \\
(1.52)\end{array}$ \\
\hline $\begin{array}{l}\text { Nb. of months migrated since } \\
1997\end{array}$ & $\begin{array}{l}0.008 \\
(0.81)\end{array}$ & $\begin{array}{l}0.008 \\
(0.84)\end{array}$ & $\begin{array}{l}0.009 \\
(0.90)\end{array}$ & $\begin{array}{l}0.009 \\
(0.92)\end{array}$ \\
\hline
\end{tabular}


Table 5. The determinants of life satisfaction - (follows)

\begin{tabular}{lcccc}
\hline & $\begin{array}{c}\text { Ordered Probit on } \\
\text { Happiness in 2003 }\end{array}$ & $\begin{array}{c}\text { Ordered Probit on } \\
\text { Happiness in 2003 }\end{array}$ & $\begin{array}{c}\text { Ordered Probit on } \\
\text { Happiness in 2003 }\end{array}$ & $\begin{array}{c}\text { Ordered Probit on } \\
\text { Happiness in 2003 }\end{array}$ \\
\hline Dummy Individual migrated in & & & & -0.602 \\
Greece between 1997 and 2001 & -0.608 & -0.608 & $(1.32)$ & -0.602 \\
Dummy Individual migrated in & $(1.33)$ & $(1.33)$ & -0.646 & $(1.32)$ \\
Italy between 1997 and 2001 & -0.664 & -0.666 & $(1.29)$ & -0.647 \\
& $(1.32)$ & $(1.32)$ & 0.398 & $(1.29)$ \\
Year 2002: Distance in minutes & 0.402 & 0.418 & $(0.91)$ & 0.416 \\
from nearest primary school & $(0.92)$ & $(0.96)$ & 0.190 & $(0.95)$ \\
Year 2002: Distance in minutes & 0.151 & 0.131 & $(0.61)$ & 0.166 \\
from nearest ambulatory doctor & $(0.49)$ & $(0.42)$ & -0.210 & $(0.53)$ \\
Year 2002: Distance in minutes & -0.223 & -0.201 & $(0.83)$ & -0.185 \\
from nearest bus stop & $(0.88)$ & $(0.79)$ & 1024 & $(0.73)$ \\
Observations & 1024 & 1024 & -878.44 & 1024 \\
Log likelihood & -876.67 & -876.13 & 0.17 & -878.03 \\
Pseudo R-square & 0.17 & 0.17 & & 0.17 \\
\hline Source: & & & \\
\hline
\end{tabular}

Source: Authors' calculations on Albania LSMS (2002/2003)

Dummies for districts estimated but not reported

Absolute value of $\mathrm{z}$ statistics in parentheses

* significant at $10 \%$; ** significant at $5 \%$;*** significant at $1 \%$ 
Table 6. The determinants of changes in happiness

\begin{tabular}{|c|c|c|}
\hline & $\begin{array}{c}(1) \\
\text { Ordered Probit on } \\
\text { Delta Happiness } \\
\mathbf{2 0 0 3 / 2 0 0 2}\end{array}$ & $\begin{array}{c}(2) \\
\text { Ordered Probit } \\
\text { on Delta Happiness } \\
\mathbf{2 0 0 3 / 2 0 0 2}\end{array}$ \\
\hline Delta Income 2003/2002 & $\begin{array}{c}0.003 * * * \\
(2.84)\end{array}$ & $\begin{array}{c}0.002 * * * \\
(2.83)\end{array}$ \\
\hline Share of income from social assistance in 2002 & $\begin{array}{l}0.054 \\
(0.56)\end{array}$ & $\begin{array}{l}0.066 \\
(0.69)\end{array}$ \\
\hline Share of income from remittances in 2002 & $\begin{array}{l}0.079 \\
(0.46)\end{array}$ & \\
\hline Dummy if share of remittance is lower than $25 \%$ of total income & & $\begin{array}{l}-0.058 \\
(0.38)\end{array}$ \\
\hline Dummy if share of remittance is larger than $25 \%$ of total income & & $\begin{array}{l}0.130 \\
(1.06)\end{array}$ \\
\hline Dummy Employment status: ILO definition unemployed in 2002 & $\begin{array}{c}-0.574 * * * \\
(2.66)\end{array}$ & $\begin{array}{c}-0.584 * * * \\
(2.70)\end{array}$ \\
\hline Economic Status, 10 step ladder $1=$ poorest $-10=$ richest & $\begin{array}{c}-0.211 * * * \\
(8.76)\end{array}$ & $\begin{array}{c}-0.212 * * * \\
(8.77)\end{array}$ \\
\hline Year 2002: Age in years & $\begin{array}{c}-0.009 * * * \\
(2.62)\end{array}$ & $\begin{array}{c}-0.009 * * * \\
(2.67)\end{array}$ \\
\hline Year 2002: Years of education & $\begin{array}{c}0.031 * * * \\
(2.86)\end{array}$ & $\begin{array}{c}0.031 * * * \\
(2.88)\end{array}$ \\
\hline Year 2002: Dummy for married & $\begin{array}{c}-0.858 \\
(0.77)\end{array}$ & $\begin{array}{l}-0.858 \\
(0.77)\end{array}$ \\
\hline Year 2002: Dummy for divorced & $\begin{array}{l}-0.944 \\
(0.82)\end{array}$ & $\begin{array}{l}-0.947 \\
(0.82)\end{array}$ \\
\hline Year 2002: Dummy for widow & $\begin{array}{l}-0.812 \\
(0.73)\end{array}$ & $\begin{array}{l}-0.807 \\
(0.72)\end{array}$ \\
\hline Year 2002: Dummy for single & $\begin{array}{l}-0.956 \\
(0.84)\end{array}$ & $\begin{array}{l}-0.954 \\
(0.84)\end{array}$ \\
\hline Year 2002: Dummy for religion: Muslim & $\begin{array}{l}-0.092 \\
(0.39)\end{array}$ & $\begin{array}{l}-0.101 \\
(0.42)\end{array}$ \\
\hline Year 2002: Dummy for religion: Orthodox & $\begin{array}{l}0.082 \\
(0.32)\end{array}$ & $\begin{array}{l}0.073 \\
(0.29)\end{array}$ \\
\hline Year 2002: Dummy for religion: Catholic & $\begin{array}{l}0.368 \\
(1.28)\end{array}$ & $\begin{array}{l}0.351 \\
(1.22)\end{array}$ \\
\hline Number of visit to public ambulatory in last month in 2002 & $\begin{array}{l}0.034 \\
(0.71)\end{array}$ & $\begin{array}{l}0.031 \\
(0.65)\end{array}$ \\
\hline Costs associated with outpatient visits to public ambulatory in 2002 & $\begin{array}{l}0.045 \\
(0.05)\end{array}$ & $\begin{array}{l}0.031 \\
(0.03)\end{array}$ \\
\hline Value of gifts made to medical staff of public ambulatory in 2002 & $\begin{array}{l}0.429 \\
(0.19)\end{array}$ & $\begin{array}{l}0.506 \\
(0.23)\end{array}$ \\
\hline Dummy ever migrated since 1997 & $\begin{array}{c}0.725^{*} \\
(1.77)\end{array}$ & $\begin{array}{c}0.716^{*} \\
(1.75)\end{array}$ \\
\hline Nb. of months migrated since 1997 & $\begin{array}{l}-0.008 \\
(0.81)\end{array}$ & $\begin{array}{l}-0.008 \\
(0.79)\end{array}$ \\
\hline Dummy Individual migrated in Greece between 1997 and 2001 & $\begin{array}{l}-0.393 \\
(0.93)\end{array}$ & $\begin{array}{l}-0.389 \\
(0.92)\end{array}$ \\
\hline Dummy Individual migrated in Italy between 1997 and 2001 & $\begin{array}{l}-0.739 \\
(1.62)\end{array}$ & $\begin{array}{l}-0.735 \\
(1.62)\end{array}$ \\
\hline Year 2002: Distance in minutes from nearest primary school & $\begin{array}{l}0.667 \\
(1.61)\end{array}$ & $\begin{array}{l}0.662 \\
(1.60)\end{array}$ \\
\hline Year 2002: Distance in minutes from nearest ambulatory doctor & $\begin{array}{l}-0.276 \\
(0.94)\end{array}$ & $\begin{array}{l}-0.285 \\
(0.97)\end{array}$ \\
\hline Year 2002: Distance in minutes from nearest bus stop & $\begin{array}{c}-0.409^{*} \\
(1.71)\end{array}$ & $\begin{array}{c}-0.403^{*} \\
(1.69)\end{array}$ \\
\hline Observations & 1020 & 1020 \\
\hline Log likelihood & -1069.84 & -1069.22 \\
\hline Pseudo R-square & 0.09 & 0.09 \\
\hline
\end{tabular}

Source: Authors' calculations on Albania LSMS (2002/2003)

Dummies for districts estimated but not reported

Absolute value of $\mathrm{z}$ statistics in parentheses

* significant at $10 \%$; * significant at $5 \%$; *** significant at $1 \%$ 